\title{
Female heterozygous (+/fa) Zucker rats as a novel leptin-related mammary carcinogenesis model
}

\author{
Young-Man Cho', Toshio Imai ${ }^{2}$, Shigeaki Takami', Kumiko Ogawa ${ }^{1}$ \\ and Akiyoshi Nishikawa ${ }^{1}$
}

\begin{abstract}
${ }^{1}$ Division of Pathology, National Institute of Health Sciences, 1-18-1 Kamiyoga, Setagaya-Ku, Tokyo 158-8501, Japan ${ }^{2}$ Central Animal Division, National Cancer Center Research Institute, 5-1-1 Tsukiji, Chuo-ku, Tokyo 104-0045, Japan
\end{abstract}

(Received June 1, 2012; Accepted August 18, 2012)

\begin{abstract}
The homozygous mutant fatty Zucker rat $(f a l f a)$ is the prominent model for the research of obesity, one of the most well-known risk factor of postmenopausal mammary cancer. But the usage as a mammary gland carcinogenesis model is considered to be restricted due to the hypoplasia of mammary gland. In the present study, to find the validity of heterozygous mutant $(+/ f a)$ lean Zucker rats as a new leptin-related mammary carcinogenesis model, we examined whether the number of terminal end buds of mammary gland, the serum biochemistry, leptin concentration in serum and adipose tissue are changed in 7-week-old female $+/+,+/ f a$ and $f a / f a$ rats, and whether these changes and leptin, TNF- $\alpha$ and VEGF mRNA expression in adipose tissue of $+/+$ and $+/ f a$ rats are influenced by $10 \%$ corn oil diet for 5 weeks. We confirmed that mild hyperleptinemia was more pronounced in 7-week-old $+/ f a$ as compared with wild type (+/+) and hypoplasia of mammary glands characterized by fewer numbers of terminal end buds in $f a l f a$ was not observed in $+/ f a$. With $10 \%$ corn oil diet, leptin mRNA expression in adipose tissue showed increasing tendency both in $+/ f a$ and $+/+$. Comparing with $+/+$, adipose tissue in $+/ f a$ treated with $10 \%$ corn oil diet was found to be significantly increased in the concentration of leptin protein and tended to be elevated expression of TNF- $\alpha$ mRNA. These results suggest that $+/ f a$ with $10 \%$ corn oil diet may be a useful model for investigation of the participation of leptin and TNF- $\alpha$ in mammary gland carcinogenesis.
\end{abstract}

Key words: Leptin, Tumor models, Mammary cancer

\section{INTRODUCTION}

General obesity is an important risk factor of mammary cancer in postmenopausal women, and central obesity was further reported to increase mammary cancer risk in premenopausal as well as postmenopausal populations (Calle and Thun, 2004; Phillips et al., 1996; Schaffler et al., 2007). The mechanisms involved remain largely unclear, but it is suggested that various bioactive factors synthesized by adipose tissue might exert tumorstimulatory effects on the mammary gland epithelium (Caldefie-Chezet et al., 2005; Housa et al., 2006). One principal bioactive substance produced by adipocytes is leptin (Anubhuti and Arora, 2008), a 167-aminoacid peptide hormone encoded by the obesity gene $(o b)$, which is secreted and plays important roles in regulating food intake and energy expenditure through binding to specific receptors (OB-R) (Anubhuti and Arora, 2008). Lep- tin also controls other common physiological processes such as immune responses, cell differentiation, proliferation and angiogenesis (Zhang et al., 2005). Furthermore, several evidences suggest that leptin could be involved in tumorigenesis as a mitogenic, transforming or migration factor, especially active in the development of mammary, colorectal and prostate cancers (Garofalo and Surmacz, 2006; Hu et al., 2002; Rouet-Benzineb et al., 2004; Somasundar et al., 2004).

Both leptin and OB-R appear to be significantly overexpressed in human mammary cancer tissue relative to non-cancer epithelium (Ishikawa et al., 2004). In addition, higher expression of OB-R protein has been demonstrated in estrogen receptor $\alpha(\mathrm{ER} \alpha)$-positive human mammary carcinoma cells MCF-7 and T47D than ER $\alpha-$ negative carcinoma cells MDA-MB-231 and MDA-MB 435 (Garofalo et al., 2004). Leptin stimulates estrogen production through enhanced aromatase mRNA expres-

Correspondence: Young-Man Cho (E-mail: ymcho@nihs.go.jp) 
sion, protein content and enzymatic activity in MCF-7, via AP-1 (Catalano et al., 2003). In general, elevated lifetime estrogen exposure is considered a major risk factor for mammary cancer in human (Key et al., 2002). Leptin signaling is also reported to play an important role in the growth of mammary cancers through promotion of the expression of vascular endothelial growth factor (VEGF)/vascular endothelial growth factor receptor type 2 (VEGFT2) (Rene Gonzalez et al., 2009). Moreover, its synthesis is influenced most notably by tumor necrosis factor- $\alpha$ (TNF- $\alpha$ ) (Zhang et al., 2000), insulin (Cusin et al., 1995) and reproductive hormones (MachinalQuelin et al., 2002), all of which have been associated with mammary gland neoplastic processes. For example, there is evidence that hyperinsulinemia promotes mammary cancer progression through leptin-dependent mechanisms (Bartella et al., 2008; Garofalo et al., 2006). Estrogen regulates leptin productions in rats and humans subjects in vivo (Alonso et al., 2007; Shimizu et al., 1997).

TNF- $\alpha$ is a multifunctional cytokine that plays important roles in diverse cellular events such as immune function, cell survival, proliferation, differentiation, and death (Wang and Lin, 2008). Administration of TNF- $\alpha$ increased leptin mRNA and protein levels in adipose tissue of hamsters (Grunfeld et al., 1996). Adipose tissues of the obese $d b / d b, o b / o b, t u b / t u b$ mice, and the fa/fa Zucker rat expressed high levels of TNF- $\alpha$ mRNA and circulating plasma levels of TNF- $\alpha$ protein significantly elevated in $d b / d b$ mice (Hotamisligil et al., 1993). TNF- $\alpha$, a proinflammatory cytokine, has been shown to be synthesized and secreted from macrophage as well as adipocyte (Kern et al., 1995; Weisberg et al., 2003), which may be involved in inflammation-associated carcinogenesis (Balkwill, 2009).

In animal models, a higher body weight is linked with increased incidences of both spontaneous and chemically induced mammary tumors (Haseman et al., 1994; Waxler et al., 1953; Wolff et al., 1982). Zucker rats with a homogeneous spontaneous mutation in the leptin receptor gene $(f a / f a)$ (Phillips et al., 1996) are known to be obese, hyperphagic and hyperinsulinemic (Bray, 1977). In contrast, lean Zucker $(+/ f a$ or $+/+)$ rats show almost normal metabolic functions, and have been used as controls in various types of physiochemical and pathological experiments (Bray, 1977). The Zucker rat has been recognized as a superior model to investigate effects of obesity on chronic disease development, including cancer (Bray, 1977; de Assis et al., 2006; Hakkak et al., 2007), but its utility for investigations of mammary carcinogenesis is limited due to scant epithelial development in mature mammary glands of obese as compared with lean counterparts (Hu et al., 2002). Since it was reported that young heterozygous lean Zucker $(+/ f a)$ rats demonstrate a number of differences from wild type lean Zucker $(+/+)$ rats, e.g., higher body weights, fat cell size, inguinal fat pad weights, pad-to-body weight ratios, serum cholesterol, adipose tissue lipoprotein lipase and glycerol-3-phosphate dehydrogenase, hepatic and adipose tissue 6-phosphogluconate dehydrogenase activities and serum leptin levels $(1.6$ and $0.9 \mathrm{ng} / \mathrm{ml}$ in $+/ f a$ and $+/+$, respectively, (Cleary and Phillips, 1999)) (Cleary et al., 1999; Heo et al., 2002; Phillips and Cleary, 1994; Truett et al., 1995; Zhang et al., 1997), we here investigated whether they might provide the basis for a leptin-related mammary carcinogenesis model. Two independent experiments were performed. In experiment 1 , serum biochemistry, histological characteristics of mammary glands and leptin levels of serum and adipose tissue in 7-week-old female $+/ f a$ lean Zucker rats were compared with those of $f a / f a$ and $+/+$ siblings. In experiment 2 , we tested whether $10 \%$ corn oil diet affects serum biochemistry and histological characteristics of mammary glands as well as leptin, TNF- $\alpha$ and VEGF mRNA expression in adipose tissue of female $+/ f a$ and $+/+$ lean Zucker rats.

\section{MATERIALS AND METHODS}

\section{Animals}

Homozygous obese $(f a / f a)$, heterozygous lean $(+/ f a)$ and wild type $(+/+)$ female Zucker rats at 6 weeks of age were purchased from Charles River Japan (Kanagawa, Japan). They were housed in clear polycarbonate cages with heat-treated white wood chips for bedding (Sankyo Laboratory Service, Tokyo, Japan) in an air conditioned room $\left(24 \pm 1^{\circ} \mathrm{C}, 55 \pm 5 \%\right.$ relative humidity, $12 \mathrm{hr}$ light and dark cycle) and given basal diet (CRF-1, Oriental Yeast, Tokyo, Japan) and tap water ad libitum. The composition of the basal diet is $22.4 \%$ crude protein, $5.7 \%$ crude fat, $6.6 \%$ crude ash, $3.1 \%$ crude fiber, $7.8 \%$ moisture content and $54.5 \%$ nitrogen-free extract and the calorie of cereal-based diet is $359 \mathrm{kcal} / 100 \mathrm{~g}$. The present study design was approved by the Animals Care and Utilization Committee of the National Institute of Health Sciences.

\section{Genotyping}

The animals were divided into each genotype group on the basis of genotyping, as described previously (Phillips et al., 1996). For polymerase chain reaction (PCR) amplification of DNA sequences encoding leptin receptor isoform, digested $0.5 \mathrm{~mm}$ tail samples were amplified with the primers 5'-GTTTGCGTATGGAAGTCACAG-3' and 
+/fa Zucker as mammary carcinogenesis model

5'-ACCAGCAGAGATGTATCCGAG3' at the annealing temperature of $67^{\circ} \mathrm{C}$ for 30 cycles. The PCR products were incubated with $\mathrm{MspI}$ for $1 \mathrm{hr}$ at $37^{\circ} \mathrm{C}$ to indicate the presence of the mutation-derived restriction site in Zucker rat genomic DNA.

\section{Experiment 1}

Female Zucker rats $(+/+, \mathrm{n}=8 ;+/ f a, \mathrm{n}=16 ; f a / f a$, $\mathrm{n}=6)$ at 7 -weeks of age were weighed and sacrificed without overnight fasting and blood samples were collected from the abdominal aorta under ether anesthesia for serum biochemistry and leptin and insulin enzyme assays. Serum biochemistry measurements of glucose, triglyceride (TG), total cholesterol (T-Cho) and a double antibody radioimmunoassay for estradiol were performed at SRL (Tokyo, Japan). Leptin levels in serum and homogenates of adipose tissue that carefully excluded their mammary gland from the one side of an inguinal fat pad and serum insulin levels were measured with an enzyme-linked immunosorbent assay (ELISA) kit, YK050 (Yanaihara Institute, Shizuoka, Japan) and by rat insulin ELISA (Mercodia AB, Uppsala, Sweden), respectively, according to the manufacturer's instructions. After macroscopic observation of abdominal viscera, subcutis and inguinal fat pads, liver and remaining inguinal fat pads containing mammary gland tissue were removed and fixed in $10 \%$ neutral buffered formalin for routine preparation of paraffin-embedded sections, then, hematoxylin and eosin (H.E.) staining and immunohistochemical analysis were performed. Livers were weighed before processing. The other side of inguinal fat pad in each animal was used for whole-mount preparation.

\section{Experiment 2}

Female Zucker rats at 7 -weeks of age were fed basal $(+/+, \mathrm{n}=5 ;+/ f a, \mathrm{n}=6)$ or basal diet $+10 \%$ corn oil $(+/+$, $\mathrm{n}=14 ;+/ f a, \mathrm{n}=15)$ for 5 weeks and then sacrificed without overnight fasting in the same manner with experimental 1 . In addition to the measured items in experiment 1 except serum estradiol concentration and total number of TEB in whole-mount preparation, expression of mRNAs for leptin, tumor necrosis factor- $\alpha$ (TNF- $\alpha$ ), vascular endothelial growth factor A (VEGFA) and aromatase in inguinal adipose tissue was analyzed using realtime reverse transcription (RT)-PCR.

\section{Mammary gland whole mounts and quantification}

The whole-mount preparation protocol was a modification of previously described procedures (You et al., 2002). Freshly dissected inguinal fat pad containing mammary glands tissues were placed flat between a pair of glass slides and fixed in 10\% formalin for $24 \mathrm{hr}$, then dehydrated with 70, 95 and $100 \%$ ethanol (about $3 \mathrm{hr}$ in each). The samples were defatted in acetone for approximately $12 \mathrm{hr}$ and rehydrated in diluted ethanol solution ranging from 100 to $40 \%$ for $3 \mathrm{hr}$ each. The samples were stained with $0.005 \%$ toluidine blue for $30 \mathrm{~min}$ and then dehydrated again in ethanol solution. The tissue pieces were then finally immersed in xylene for approximately $6 \mathrm{hr}$ and mounted on glass slides with a mounting agent. The total numbers of terminal end buds (TEB) were counted from the distal portions of the mammary gland under a stereomicroscope, according to the criteria of Russo (Russo et al., 1990).

\section{Immunohistochemistry}

The streptavidin-biotin peroxidase complex method (StreptABComplex/HRP, DAKO, Glostrup, Denmark) was used to determine the expression and localization of leptin and leptin receptors in mammary glands and inguinal adipose tissue of Zucker rats at 7 and 12 weeks of age. Polyclonal antibodies against leptin $(\mathrm{Ob})$ were purchased from Santa Cruz Biotechnology (A-20; Santa Cruz, CA, USA) and used at a dilution of $1 / 100$. A polyclonal antibody against the leptin receptor (OB-R) recognizing both wild and mutant forms was accessed from Neuromics Antibodies (Edina, MN, USA) and used at $1 / 1000$. Antigen retrieval was performed in an autoclave for $10 \mathrm{~min}$ at $121^{\circ} \mathrm{C}$ in $10 \mathrm{mM}$ citrate buffer (pH 6.0) for leptin receptors. Sections were lightly counterstained with hematoxylin for microscopic examination. Negative controls without primary antibodies were included for each antigen using serial sections.

\section{Real-time RT-PCR}

Quantitative real-time RT-PCR using an ABI Prism 7000 sequence detection system (Applied Biosystems Japan, Tokyo, Japan) was performed for leptin (Lep), TNF- $\alpha$ (Tnf), VEGFA(Vegfa) and aromatase (Cyp 19al). One microgram aliquots of total RNA isolated from inguinal fat pads of all rats and from ovaries and livers of basal diet $+/+$ as positive and negative control of aromatase, respectively, in experiment 2 using Isogen ${ }^{\mathrm{TM}}$ (Nippon Gene, Tokyo, Japan) were applied to RT with a High-Capacity cDNA Archive Kit (Applied Biosystems Japan, Tokyo, Japan) in a $100 \mu$ l total reaction volume. For real-time PCR analysis, ABI Assays-on-DemandTM TaqMan probe and primer sets from Applied Biosystems (available at https://products.appliedbiosystems. $\mathrm{com} / \mathrm{ab} / \mathrm{en} / \mathrm{US} /$ adirect/ab? $\mathrm{cmd}=$ catNavigate $2 \&$ catID $=601$ 267/) were employed. Real-time PCR was performed in a $50-\mu 1$ reaction volume using the TaqMan probe detection 
system (Applied Biosystems Japan) with specific primers, the corresponding TaqMan ${ }^{\mathrm{TM}}$ MGB probes $\left(\mathrm{FAM}^{\mathrm{TM}}\right.$ dye labeled) and RT products. For the quantification of expression data, a standard curve method and normalization with a housekeeping gene, hypoxanthine-guanine phosphoribosyltransferase were applied.

\section{Statistical analysis}

Variance in data was checked for homogeneity by Bartlett's procedure. When the data were homogeneous, one-way analysis of variance for homogeneity (ANOVA) was used. In the heterogeneous cases, the Kruskal Wallis test was applied. When statistically significant differences were indicated, the Dunnett's multiple test was employed for comparisons between groups; in experiment 1, among all groups; in experiment $2,+/+$ basal diet vs. $+/+10 \%$ corn oil, $+/+$ basal diet vs. $+/ f a$ basal diet, $+/+10 \%$ corn oil vs. $+/ f a 10 \%$ corn oil and $+/ f a$ basal diet vs. $+/ f a$ $10 \%$ corn oil. Value are presented as means \pm standard deviations or standard error. $p$ values of less than 0.05 were considered to be statistically significant. .

\section{RESULTS}

\section{Experiment 1}

In female fatty $(f a / f a)$ Zucker rats at 7-weeks old of age, body weights and absolute and relative liver weights were higher $(\mathrm{p}<0.05$ or 0.01$)$ than those of lean $+/+$ and $/$ or $+/ f a$ rats (Table 1) and excess accumulation of adipose tissue in abdominal viscera, subcutis and inguinal fat pads at necropsy and increased storage of hepatocellular glycogen on histopathology were observed. There were higher $(\mathrm{p}<0.05$ or 0.01$)$ concentrations of serum TG, T-Cho and insulin in $f a / f a$ rats than in $+/+$ and/or $+/ f a$ rats, but not of glucose and estradiol (Table 2). No difference of body and liver weights and serum T-Cho, TG and insulin values were observed between $+/+$ and $+/ f a$ rats. Leptin concentrations in serum and adipose tissue were higher ( $\mathrm{p}<0.05$ or 0.01 ) in $f a / f a$ rats than $+/+$ and $+/ f a$ rats, and those of serum were also higher in $+/ f a$ rats $(\mathrm{p}<0.05)$ than in $+/+$ rats (Table 3 ).

With inguinal mammary gland whole mounts, poorly developed tissue characterized by thinner ducts and immature glands and lower $(\mathrm{p}<0.01)$ numbers of TEB (Fig. 1) was observed in female fatty $(f a / f a)$ Zucker rats at 7-week old of age, as compared with lean $+/+$ and $+/$ $f a$ rats. Immunohistochemical analysis revealed that adipocytes in inguinal fat pad express leptin and its intensity was increased in hypertrophied adipocytes of $f a / f a$ rats as compared with $+/+$ and $+/ f a$ (data not shown). Ductal and glandular epithelium of mammary gland of all genotypes showed positive reaction to an anti-leptin receptor antibody that recognized both wild and mutant form (data not shown).

Table 1. Experiment 1; body and liver weights

\begin{tabular}{lcccc}
\hline Genotype & $\mathrm{N}$ & $\begin{array}{c}\text { Body weight } \\
(\mathrm{g})\end{array}$ & $\begin{array}{c}\text { Absolute liver weight } \\
(\mathrm{g})\end{array}$ & $\begin{array}{c}\text { Relative liver weight } \\
(\mathrm{g} / 100 \mathrm{~g} \text { b.w. })\end{array}$ \\
\hline$+/+$ & 8 & $152 \pm 3^{\mathrm{a}}$ & $7.1 \pm 0.4$ & $4.7 \pm 0.2$ \\
$+/ f a$ & 16 & $153 \pm 8$ & $7.2 \pm 1.0$ & $4.7 \pm 0.5$ \\
$f a / f a$ & 6 & $222 \pm 9^{* *, \# \#}$ & $11.5 \pm 1.3^{* *, \# \#}$ & $5.2 \pm 0.4^{\#}$ \\
\hline
\end{tabular}

N: No. of animals. a: Mean \pm S.D.

$* *$ : Significantly different from $+/+$ at $\mathrm{p}<0.01$ (Dunnett's multiple test).

$\#, \#$ : Significantly different from $+/ f a$ at $\mathrm{p}<0.05$ and 0.01 , respectively (Dunnett's multiple test).

Table 2. Experiment 1; serum biochemistry

\begin{tabular}{lcccccc} 
Genotype & $\mathrm{N}$ & $\begin{array}{c}\text { Glucose } \\
(\mathrm{mg} / \mathrm{dl})\end{array}$ & $\begin{array}{c}\text { Triglyceride } \\
(\mathrm{mg} / \mathrm{dl})\end{array}$ & $\begin{array}{c}\text { Total cholesterol } \\
(\mathrm{mg} / \mathrm{dl})\end{array}$ & $\begin{array}{c}\text { Insulin } \\
(\mathrm{ug} / \mathrm{l})\end{array}$ & $\begin{array}{c}\text { Estradiol } \\
(\mathrm{pg} / \mathrm{ml})\end{array}$ \\
\hline$+/+$ & 8 & $142 \pm 7^{\mathrm{a}}$ & $153 \pm 44$ & $90 \pm 11$ & $1.2 \pm 0.3$ & $34 \pm 30^{\mathrm{b}}$ \\
$+/ f a$ & 16 & $149 \pm 28$ & $165 \pm 50$ & $87 \pm 7$ & $1.4 \pm 0.6$ & $24 \pm 13^{\mathrm{c}}$ \\
$\mathrm{fa} / \mathrm{fa}$ & 6 & $155 \pm 40$ & $302 \pm 134^{\#}$ & $129 \pm 14^{* *, \#}$ & $6.8 \pm 6.0^{* * * \#}$ & $19 \pm 10$ \\
\hline
\end{tabular}

N: No. of animals. ${ }^{a}:$ Mean \pm S.D. ${ }^{b}: n=7 c: n=15$

**: Significantly different from $+/+$ at $\mathrm{p}<0.01$ (Dunnett's multiple test)

\#,\#\#: Significantly different from $+/ f a$ at $\mathrm{p}<0.05$ and 0.01 , respectively (Dunnett's multiple test) 
a

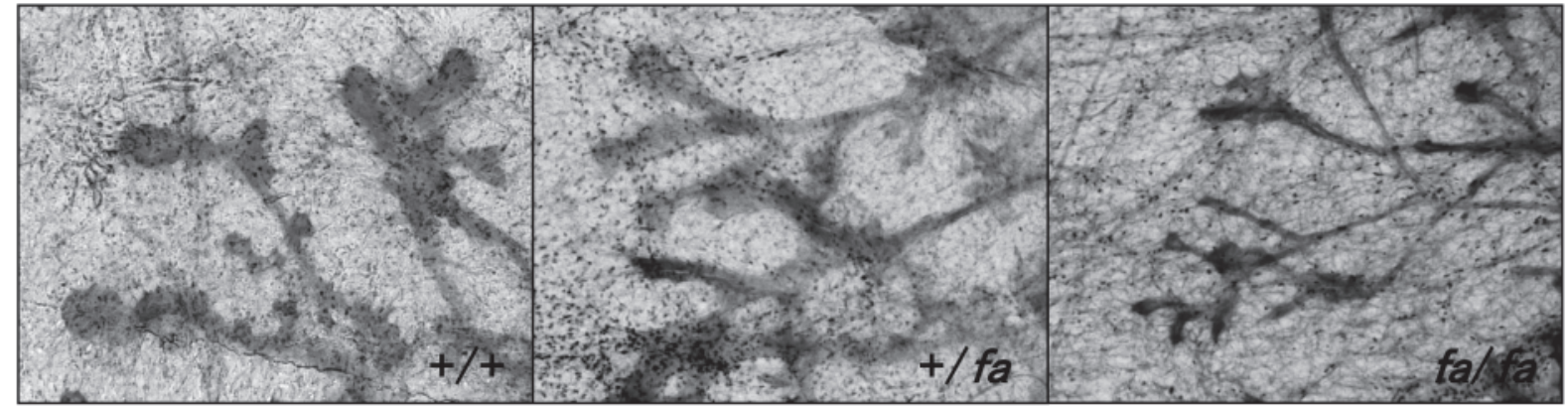

b
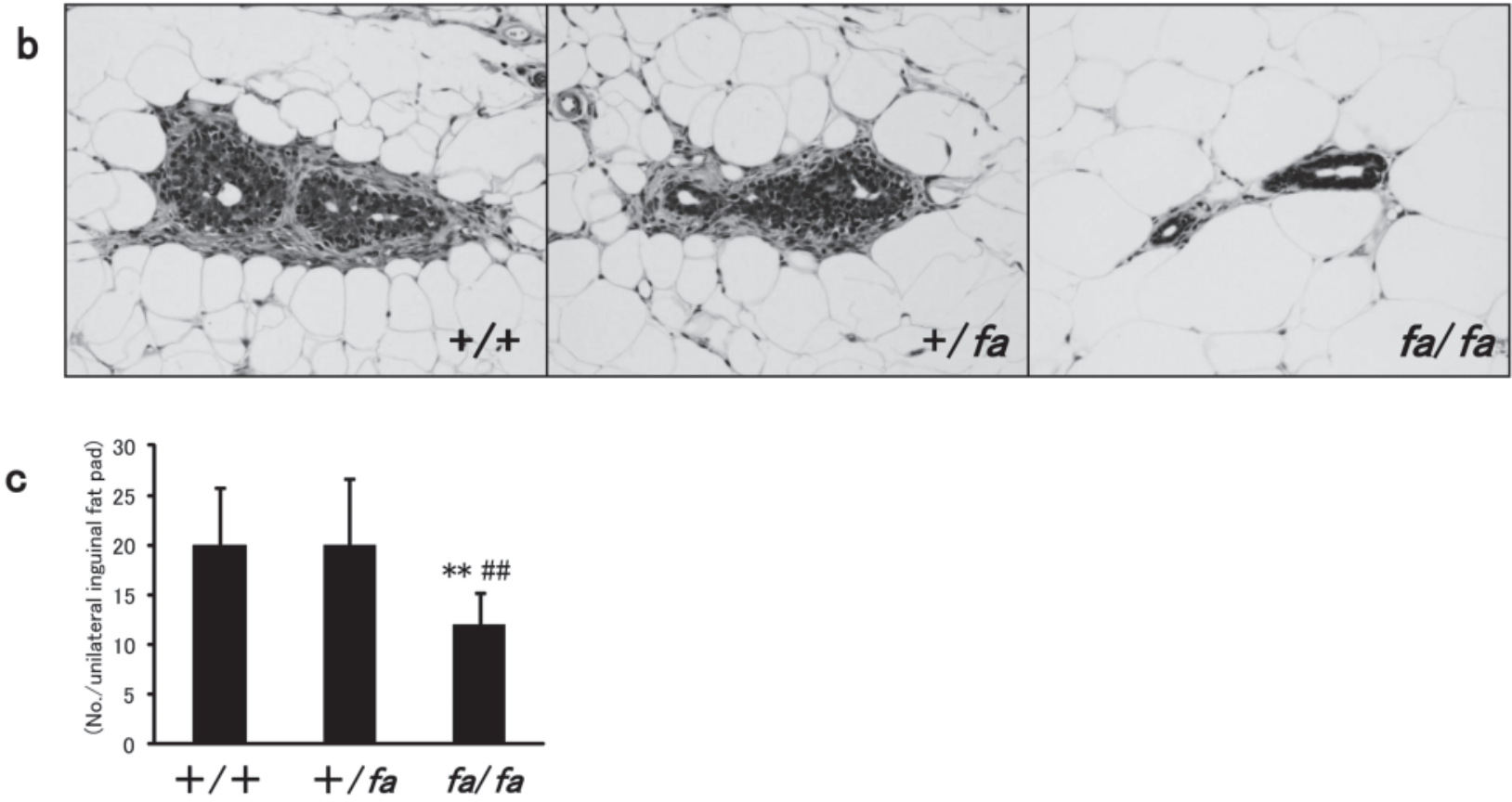

Fig. 1. Experiment 1; representative whole-mount preparation (a, toluidine blue staining, original magnification $\mathrm{x} 40$ ), histology (b, HE staining, original magnification x200) and numbers of terminal end buds (TEBs) (c) of mammary tissue of 7-weekold female Zucker rats. Poorly developed tissue characterized by thinner ducts and immature glands and lower numbers of TEB was noted in female fatty $(f a / f a, \mathrm{n}=6)$ Zucker rats at 7 -week old of age, comparing with $+/+(\mathrm{n}=8)$ and $+/ f a(\mathrm{n}=16)$ rats. $* *$ : Significantly different from $+/+$ at $\mathrm{p}<0.01$. \#\#: Significantly different from $+/ f a$ at $\mathrm{p}<0.01$.

Table 3. Experiment 1; leptin levels in serum and adipose tissue

\begin{tabular}{lccc}
\hline Genotype & $\mathrm{N}$ & $\begin{array}{c}\text { Serum leptin } \\
(\mathrm{ng} / \mathrm{ml})\end{array}$ & $\begin{array}{c}\text { Adipose tissue leptin } \\
(\mathrm{ng} / \mathrm{g})\end{array}$ \\
\hline$+/+$ & 8 & $0.08 \pm 0.02^{\mathrm{a}}$ & $1.3 \pm 0.6$ \\
$+/ f a$ & 16 & $0.14 \pm 0.05^{*}$ & $1.6 \pm 1.0$ \\
$\mathrm{fa} / \mathrm{fa}$ & 6 & $1.24 \pm 0.13^{* *, \#}$ & $8.5 \pm 1.6^{* *, \#}$ \\
\hline
\end{tabular}

N: No. of animals. a: Mean \pm S.D.

$*, * *$ : Significantly different from $+/+$ at $\mathrm{p}<0.05$ and 0.01 , respectively (Dunnett's multiple test)

\#,\#\#: Significantly different from $+/ f a$ at $\mathrm{p}<0.05$ and 0.01 , respectively (Dunnett's multiple test)

\section{Experiment 2}

In $+/ f a$ rats significantly higher final body weight $(\mathrm{p}<0.01)$ was shown in rats fed $10 \%$ corn oil when compared with rats fed basal diet (Table 4 ). In $+/$ fa rats fed $10 \%$ corn oil, absolute and relative liver weight were significantly lower than those of $+/+(p<0.05$ or 0.01 , Table 4$)$. No histopathological differences in liver and mammary glands were observed between $+/+$ and $+/ f a$ rats fed basal or $10 \%$ corn oil mixed diet for 5 weeks (data not shown). In serum biochemistry, glucose concentration $(\mathrm{p}<0.01)$ showed significantly lower values in $+/ f a$ rats as compared to $+/+$, but TG showed lower values without statis- 
Table 4. Experiment 2; final body and liver weights

\begin{tabular}{llcccc}
\hline Genotype and diet & $\mathrm{N}$ & $\begin{array}{c}\text { Body weight } \\
(\mathrm{g})\end{array}$ & $\begin{array}{c}\text { Liver weight } \\
(\mathrm{g})\end{array}$ & $\begin{array}{c}\text { Relative liver weight } \\
(\mathrm{g} / 100 \mathrm{~g} \text { b.w. })\end{array}$ \\
\hline \multirow{2}{*}{$+/+$} & Basal diet & 5 & $229 \pm 10^{\mathrm{a}}$ & $8.2 \pm 1.0$ & $3.6 \pm 0.3$ \\
& $10 \%$ Corn oil diet & 6 & $233 \pm 12$ & $8.4 \pm 0.7$ & $3.6 \pm 0.2$ \\
\hline \multirow{2}{*}{$+/ f a$} & Basal diet & 14 & $222 \pm 10$ & $7.7 \pm 0.6$ & $3.5 \pm 0.2$ \\
& $10 \%$ Corn oil diet & 15 & $235 \pm 9^{\text {ss }}$ & $7.8 \pm 0.2^{\# \#}$ & $3.3 \pm 0.1^{\#}$ \\
\hline
\end{tabular}

N: No. of animals. a: Mean \pm S.D.

\#,\#: Significantly different from $+/+10 \%$ Corn oil diet at $\mathrm{p}<0.05$ and 0.01 , respectively (Dunnett's multiple test)

ss: Significantly different from $+/ f a$ basal diet at $\mathrm{p}<0.01$ (Dunnett's multiple test)

Table 5. Experiment 2; serum biochemistry

\begin{tabular}{|c|c|c|c|c|c|c|}
\hline \multicolumn{2}{|c|}{ Genotype and diet } & \multirow{2}{*}{$\begin{array}{l}\mathrm{N} \\
5\end{array}$} & \multirow{2}{*}{$\begin{array}{c}\begin{array}{c}\text { Glucose } \\
(\mathrm{mg} / \mathrm{dl})\end{array} \\
179 \pm 24^{\mathrm{a}}\end{array}$} & \multirow{2}{*}{$\begin{array}{c}\begin{array}{c}\text { Triglyceride } \\
(\mathrm{mg} / \mathrm{dl})\end{array} \\
346 \pm 90\end{array}$} & \multirow{2}{*}{$\begin{array}{c}\text { Total cholesterol } \\
(\mathrm{mg} / \mathrm{dl})\end{array}$} & \multirow{2}{*}{$\begin{array}{c}\begin{array}{c}\text { Insulin } \\
\text { (ug/l) }\end{array} \\
1.9 \pm 1.1\end{array}$} \\
\hline 1 & Basal diet & & & & & \\
\hline$T / T$ & $10 \%$ Corn oil diet & 6 & $172 \pm 15$ & $233 \pm 77$ & $98 \pm 6$ & $1.9 \pm 0.8$ \\
\hline \multirow{2}{*}{$+/ f a$} & Basal diet & 14 & $153 \pm 13 * *$ & $239 \pm 100$ & $86 \pm 11$ & $2.0 \pm 0.9$ \\
\hline & $10 \%$ Corn oil diet & 15 & $162 \pm 15$ & $176 \pm 85$ & $84 \pm 10$ & $1.7 \pm 0.9$ \\
\hline
\end{tabular}

N: No. of animals. a: Mean \pm S.D.

**: Significantly different from $+/+$ basal diet at $\mathrm{p}<0.01$ (Dunnett's multiple test)

Table 6. Experiment 2; leptin levels in serum and adipose tissue

\begin{tabular}{|c|c|c|c|c|}
\hline \multicolumn{2}{|c|}{ Genotype and diet } & $\mathrm{N}$ & Serum leptin (ng/ml) & Adipose tissue leptin (ng/g) \\
\hline \multirow{2}{*}{$+/+$} & Basal diet & 5 & $0.2 \pm 0.1^{\mathrm{a}}$ & $3.8 \pm 1.0$ \\
\hline & $10 \%$ Corn oil diet & 6 & $0.5 \pm 0.3$ & $2.6 \pm 0.7$ \\
\hline \multirow{2}{*}{$+/ f a$} & Basal diet & 14 & $0.3 \pm 0.2$ & $4.7 \pm 2.2$ \\
\hline & $10 \%$ Corn oil diet & 15 & $0.5 \pm 0.3 *$ & $7.7 \pm 1.5^{*}$ \\
\hline
\end{tabular}

N: No. of animals. a: Mean \pm S.D.

*: Significantly different from $+/ f a$ basal diet at $\mathrm{p}<0.05$ (Dunnett's multiple test)

\#: Significantly different from $+/+10 \%$ Corn oil diet at $\mathrm{p}<0.01$ (Dunnett's multiple test)

tical significance in $+/ f a$ rats with and without $10 \%$ corn oil mixed feeding as compared to their $+/+$ counterparts (Table 5). Insulin concentrations showed similar values among all the groups, but T-Cho concentration showed lower in $+/ f a$ than $+/+$ with $10 \%$ corn oil feeding (Table 5 ). Without $10 \%$ corn oil feeding, serum and adipose tissue leptin levels in $+/ f a$ showed a non-significant tendency for elevation than in $+/+$. With $10 \%$ corn oil feeding, serum and adipose tissue leptin levels were significantly increased in $+/ f a$ than in $+/ f a$ with basal diet $(\mathrm{p}<0.05)$. Moreover, $10 \%$ corn oil feeding increased adipose tissue leptin level in $+/ f a$ than in $+/+(\mathrm{p}<0.01$, Table 6$)$.

With real-time RT-PCR analysis in adipose tissue, increased tendencies for leptin and TNF- $\alpha$ mRNA expres- sion and opposite decrease of VEGFA were observed with the $10 \%$ corn oil diet in both genotypes (Fig. 2). Regarding TNF- $\alpha$ mRNA expression, $+/ f a$ rats showed higher tendencies regardless of the diet (Fig. 2b). Expression of aromatase mRNA was detected in ovaries as a positive control, but not in adipose tissue and livers of either $+/ f a$ and $+/+$ rats (data not shown).

\section{DISCUSSION}

The present investigation of female heterozygous lean Zucker rats in comparison with $f a / f a$ and $+/+$ animals pointed to the potential of heterozygous lean Zucker rat as a possible new leptin-related mammary carcinogenesis 
+/fa Zucker as mammary carcinogenesis model
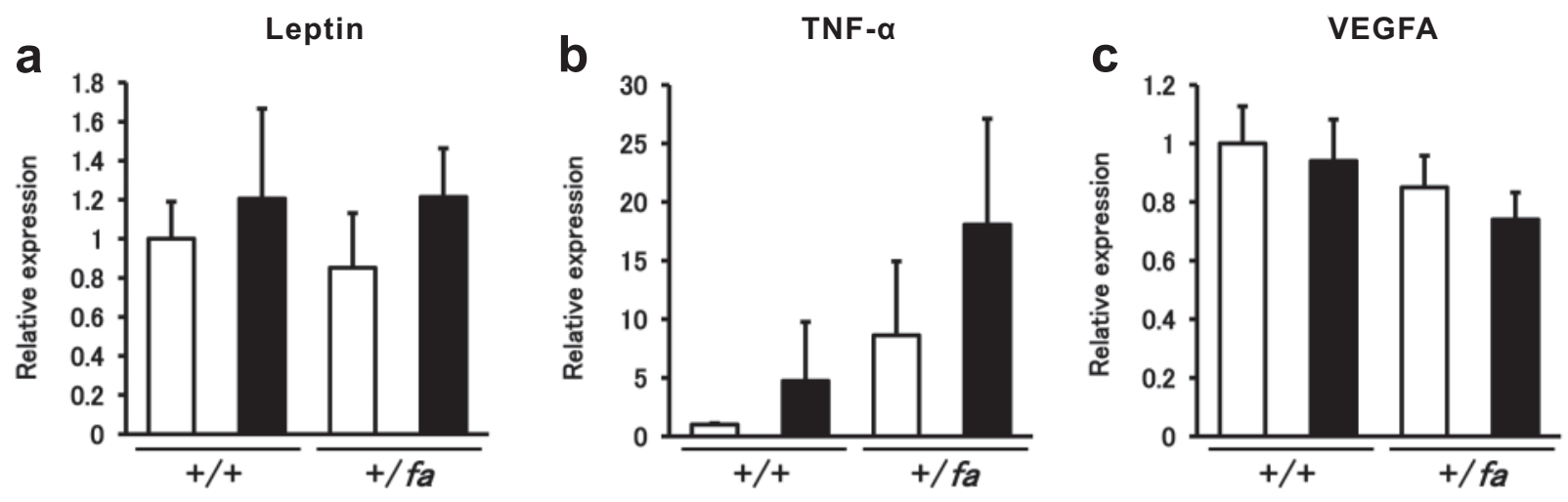

Fig. 2. Experiment 2; leptin (a), TNF- $\alpha$ (b) and VEGFA (c) mRNA expression in adipose tissue of female Zucker rats fed $10 \%$ corn oil for 5 weeks. Tendencies for slight increase of leptin and TNF- $\alpha$ expression and decrease of VEGFA were observed on feeding the $10 \%$ corn oil diet with both genotypes, but TNF- $\alpha$ expression showed higher tendencies in $+/ f a$ rats regardless of the diet. mRNA expression was normalized to the expression level of a housekeeping gene, hypoxanthine-guanine phosphoribosyltransferase. Basal diet $=$ open bar, $10 \%$ corn oil $=$ closed bar. $n=3-5$ (basal diet, $+/+), 4-6(10 \%$ corn oil, $+/+)$, 10-14 (basal diet, $+/ f a), 14-15(10 \%$ corn oil, $+/ f a)$. Values were set at 1 in $+/+$ basal diet group and expressed as mean \pm S.E. relative values.

model. While fatty falfa rats show dramatically high values for serum insulin, and serum and adipose tissue leptin, they have only few TEBs at around 7 weeks of age, when rats are reported to be most sensitive to carcinogens targeting the mammary gland (Russo et al., 1979). In contrast, lean $+/ f a$ rats feature normal mammary gland development. Corn oil-supplemented diet increased the serum leptin level. Interestingly, the increase of the leptin level in adipose tissue by $10 \%$ corn-oil diet was only observed in $+/ f a$ rat. TNF- $\alpha$ mRNA expression in $+/ f a$ was higher than in $+/+$ and further increased with corn-oil diet. All these results suggested female lean $+/ f a$ rats may be a potential model for investigation of mammary carcinogenesis in which leptin and TNF- $\alpha$ are the major related factors.

Epidemiologically mammary cancer has been shown to be associated with obesity in postmenopausal women (Calle and Thun, 2004) and hyperleptinemia is also recognized as a risk factor (Wu et al., 2009). Fatty Zucker rats with hyperleptinemia have been widely used as animal obesity model which mimics human obesity and the metabolic syndrome, and recently mammary gland carcinogenicity was investigated with 7,12-dimethylbenz(a) anthracene (DMBA) or $N$-methyl- $N$-nitrosourea (MNU)treated Zucker rat models. Hakkak et al. (2005, 2007) reported that DMBA administration by gavage at 50 days old at $65 \mathrm{mg} / \mathrm{kg}$ body weight caused more mammary tumors in female obese Zucker ( $f a l f a)$ rats than their lean $(+/ f a$ or $+/+)$ siblings. In this model, it is uncertain which obese-related parameters, e.g., hyperinsulinemia, hyperleptinemia or hyperlipidemia, affected the mammary carcinogenesis. In contrast, Lee et al. (2001) indicated that no increase in susceptibility with MNU at doses of 37.5 or $20 \mathrm{mg} / \mathrm{kg}$ body weight administered to fiftyday-old female lean $(+/ f a$ or $+/+)$ or obese Zucker $(f a /$ $f a$ ) rats. The controversial results may be partially due to the dose of administered carcinogen based on the body weight and poor development of mammary glands with low numbers of TEBs in homozygous obese Zucker rats, as shown in Fig. 1. Scant epithelial development in mammary glands were also known in non-transgenic genetically obese leptin-deficient $(o b / o b)$ and genetically obese leptin receptor-deficient $(d b / d b)$ mice as compared with their lean counterparts (Hu et al., 2002). Impaired development of mammary glands have been described in transgenic TGF- $\alpha / o b / o b$ mice (Cleary et al., 2003) and high fat diet-dependent nulliparous nonpregnant obese mice (Kamikawa et al., 2009). Leptin-dependent inhibition of cell proliferation has been reported in noncancerous mouse mammary epithelial cell line (Baratta et al., 2003; Motta et al., 2007).

It has been also reported that the reason for the poorly developed mammary gland in obese might be abnormal endogenous steroid production rather than hyperleptinemia (Marin Bivens and Olster, 1997). falfa zucker rats also show delayed vaginal opening, subsequent abnormal estrous cyclicity, undeveloped uteri and lack of deciduomata formation (Saiduddin et al., 1973) as well as 
abnormal estrous cycles (Marin Bivens and Olster, 1997). These facts suggest that young $f a / f a$ zucker rats may have disadvantage as a mammary carcinogenesis model in aspect $\mathrm{s}$ of abnormal development of mammary glands and hormone environment. Therefore, the model in which the level of leptin can be effectively controlled by some exogenous factor such as diet might be a better one. In the present study, the increase of adipose tissue leptin by corn-oil diet was more evident in $+/ f a$ than $+/+$. Maher et al. (1996) also showed that adipose tissue leptin levels was significantly higher in fat pads of $+/ f a$ compared to wild type rats and $+/ f a$ rats fed high-fat diet showed an additional two-fold increase in leptin levels compared to wild type rats on the same diet.

It was reported that adipose tissues of the obese $\mathrm{fa} / \mathrm{fa}$ Zucker rat expressed high level of TNF- $\alpha$ mRNA as compared to lean $+/+$ or $+/ f a$ (Hotamisligil et al., 1993). In the present study expression of TNF- $\alpha$ mRNA in the adipose tissue tended to be higher in $+/ f a$ Zucker rats than $+/+$ and further increased by the $10 \%$ corn oil diet, but there was no statistical significances presumably due to small number of $+/+$ and/or wide variability. TNF- $\alpha$ stimulates the release of preformed leptin from human mature adipocytes and differentiated preadipocytes (Zhang et $a l ., 2000)$, and has the ability to promote tumor progression and cancer cell dissemination (Montesano et al., 2005). TNF- $\alpha$ is synthesized and secreted from macrophage as well as adipocyte (Kern et al., 1995; Weisberg et al., 2003). Mammary glands of a diet induced obese mouse model harbored more infiltrating macrophages (Kamikawa et al., 2009), while in the present study, increased macrophage infiltration was not observed in + / $f a$ with or without the $10 \%$ corn oil diet (data not shown). Taken together, our results suggest that TNF- $\alpha$ expression may be stimulated by leptin-rich adipocyte rather than macrophage around mammary glands in $+/ f a$ and further by the $10 \%$ corn oil diet to promote leptin secretion and mammary carcinogenesis. There were no significant differences in VEGFA mRNA expression adipose tissue between our $+/ f a$ and $+/+$ rats and links with leptin gene expression are not clear (Hausman and Richardson, 2004).

Expression level of leptin mRNA in adipose tissue of 12 -week-old $+/$ fa rats did not show statistically significant differences from those of $+/+$ rats (Fig. 2a), while that of leptin protein in adipose tissue of $+/ f a$ fed with $10 \%$ corn oil was significantly higher than those of $+/+$ rats (Table 6). Our present data suggested that differences in translation efficiency, stability and efficient usage of leptin protein might be related to inconsistency of leptin mRNA expression and protein levels in $+/ f a$ rats. In addition, the adi- pose tissue leptin level in 12 week-old females $+/ f a$ is over 3 times higher than those of 7 -week-old $+/+$ in the present study. A previous study indicated that adipose tissue mRNA levels for leptin were higher in $+/ f a$ rats than $+/+$ rats at 10-days of age (Zhang et al., 1997). Leptin level in serum and leptin mRNA expression in adipose tissue in Wistar rats was increased with age (Oliver et al., 2001).

Fasting serum glucose, TG and insulin were not changed in +/fa compared to $+/+$ in many studies (Phillips and Cleary, 1994; Schwarzer et al., 1997; Zhang et al., 1997). Glucose and TG concentration showed lower values with and without statistical significance, respectively, in experiment 2 , but not in experiment 1 . Conflicting results may be partially explained by that animals were sacrificed without overnight fasting, because serum glucose and TG levels are easily affected by food consumption. On the other hand, T-Cho concentration showed lower in $+/ f a$ than $+/+$ with $10 \%$ corn oil, which may be due to cholesterol elimination promoted by increased leptin (VanPatten et al., 2001). Period of 5 weeks for diet fat supplementation is apparently shorter than that necessary for mammary carcinogenesis, but it is considered enough to examine the effects of high fat diet on the factors related to mammary carcinogenesis (Flachs et al., 2006).

In conclusion, these results suggests that $+/ f a$ rats may be a useful model for investigation of mammary carcinogenesis in which leptin and TNF- $\alpha$ are the major related factors.

\section{ACKNOWLEDGMENTS}

This work was supported in part by the Grant-in-Aid for Cancer Research (19-2) from the Ministry of Health, Labour and Welfare of Japan.

\section{REFERENCES}

Alonso, A., Fernandez, R., Moreno, M., Ordonez, P., Diaz, F. and Gonzalez, C. (2007): Leptin and its receptor are controlled by 17 beta-estradiol in peripheral tissues of ovariectomized rats. Exp. Biol. Med. (Maywood), 232, 542-549.

Anubhuti and Arora, S. (2008): Leptin and its metabolic interactions: an update. Diabetes. Obes. Metab., 10, 973-993.

Balkwill, F. (2009): Tumour necrosis factor and cancer. Nat. Rev. Cancer, 9, 361-371.

Baratta, M., Grolli, S. and Tamanini, C. (2003): Effect of leptin in proliferating and differentiated HC11 mouse mammary cells. Regul. Pept., 113, 101-107.

Bartella, V., Cascio, S., Fiorio, E., Auriemma, A., Russo, A. and Surmacz, E. (2008): Insulin-dependent leptin expression in breast cancer cells. Cancer Res., 68, 4919-4927. 
+/fa Zucker as mammary carcinogenesis model

Bray, G.A. (1977): The Zucker-fatty rat: a review. Fed. Proc., 36, 148-153.

Caldefie-Chezet, F., Damez, M., de Latour, M., Konska, G., Mishellani, F., Fusillier, C., Guerry, M., Penault-Llorca, F., Guillot, J. and Vasson, M.P. (2005): Leptin: a proliferative factor for breast cancer? Study on human ductal carcinoma. Biochem. Biophys. Res. Commun., 334, 737-741.

Calle, E.E. and Thun, M.J. (2004): Obesity and cancer. Oncogene, 23, 6365-6378.

Catalano, S., Marsico, S., Giordano, C., Mauro, L., Rizza, P., Panno, M.L. and Ando, S. (2003): Leptin enhances, via AP-1, expression of aromatase in the MCF-7 cell line. J. Biol. Chem., 278, 28668-28676.

Cleary, M.P. and Phillips, F.C. (1999): The presence of the "fa" gene in heterozygous (FA/fa) lean female rats, effects on body weight, body fat and serum leptin. Obes. Res., 7, 293-298.

Cleary, M.P., Phillips, F.C., Getzin, S.C., Jacobson, T.L., Jacobson, M.K., Christensen, T.A., Juneja, S.C., Grande, J.P. and Maihle, N.J. (2003): Genetically obese MMTV-TGF-alpha/ Lep(ob)Lep(ob) female mice do not develop mammary tumors. Breast. Cancer Res. Treat., 77, 205-215.

Cleary, M.P., Phillips, F.C. and Morton, R.A. (1999): Genotype and diet effects in lean and obese Zucker rats fed either safflower or coconut oil diets. Proc. Soc. Exp. Biol. Med., 220, 153-161.

Cusin, I., Sainsbury, A., Doyle, P., Rohner-Jeanrenaud, F. and Jeanrenaud, B. (1995): The ob gene and insulin. A relationship leading to clues to the understanding of obesity. Diabetes, $\mathbf{4 4}$, 1467-1470.

de Assis, S., Wang, M., Goel, S., Foxworth, A., Helferich, W. and Hilakivi-Clarke, L. (2006): Excessive weight gain during pregnancy increases carcinogen-induced mammary tumorigenesis in Sprague-Dawley and lean and obese Zucker rats. J. Nutr., 136, 998-1004.

Flachs, P., Mohamed-Ali, V., Horakova, O., Rossmeisl, M., Hosseinzadeh-Attar, M.J., Hensler, M., Ruzickova, J. and Kopecky, J. (2006): Polyunsaturated fatty acids of marine origin induce adiponectin in mice fed a high-fat diet. Diabetologia, 49, 394-397.

Garofalo, C., Koda, M., Cascio, S., Sulkowska, M., KanczugaKoda, L., Golaszewska, J., Russo, A., Sulkowski, S. and Surmacz, E. (2006): Increased expression of leptin and the leptin receptor as a marker of breast cancer progression: possible role of obesity-related stimuli. Clin. Cancer Res., 12, 1447-1453.

Garofalo, C., Sisci, D. and Surmacz, E. (2004): Leptin interferes with the effects of the antiestrogen ICI 182,780 in MCF-7 breast cancer cells. Clin. Cancer Res., 10, 6466-6475.

Garofalo, C. and Surmacz, E. (2006): Leptin and cancer. J. Cell. Physiol, 207, 12-22.

Grunfeld, C., Zhao, C., Fuller, J., Pollack, A., Moser, A., Friedman, J. and Feingold, K.R. (1996): Endotoxin and cytokines induce expression of leptin, the ob gene product, in hamsters. J. Clin. Invest., 97, 2152-2157.

Hakkak, R., Holley, A.W., Macleod, S.L., Simpson, P.M., Fuchs, G.J., Jo, C.H., Kieber-Emmons, T. and Korourian, S. (2005): Obesity promotes 7,12-dimethylbenz(a)anthracene-induced mammary tumor development in female zucker rats. Breast Cancer Res., 7, R627-633.

Hakkak, R., MacLeod, S., Shaaf, S., Holley, A.W., Simpson, P., Fuchs, G., Jo, C.H., Kieber-Emmons, T. and Korourian, S. (2007): Obesity increases the incidence of 7,12-dimethylbenz(a) anthracene-induced mammary tumors in an ovariectomized Zucker rat model. Int. J. Oncol., 30, 557-563.
Haseman, J.K., Bourbina, J. and Eustis, S.L. (1994): Effect of individual housing and other experimental design factors on tumor incidence in B6C3F1 mice. Fundam. Appl. Toxicol., 23, 44-52.

Hausman, G.J. and Richardson, R.L. (2004): Adipose tissue angiogenesis. J. Anim. Sci., 82, 925-934.

Heo, Y.R., Claycombe, K., Jones, B.H., Wright, P., Truett, G.E., Zemel, M., Banz, W., Maher, M. and Moustaid-Moussa, N. (2002): Effects of fatty (fa) allele and high-fat diet on adipose tissue leptin and lipid metabolism. Horm. Metab. Res., 34, 686690.

Hotamisligil, G.S., Shargill, N.S. and Spiegelman, B.M. (1993): Adipose expression of tumor necrosis factor-alpha: direct role in obesity-linked insulin resistance. Science, 259, 87-91.

Housa, D., Housova, J., Vernerova, Z. and Haluzik, M. (2006): Adipocytokines and cancer. Physiol. Res., 55, 233-244.

$\mathrm{Hu}$, X., Juneja, S.C., Maihle, N.J. and Cleary, M.P. (2002): Leptin--a growth factor in normal and malignant breast cells and for normal mammary gland development. J. Natl. Cancer Inst., 94, 1704-1711.

Ishikawa, M., Kitayama, J. and Nagawa, H. (2004): Enhanced expression of leptin and leptin receptor (OB-R) in human breast cancer. Clin. Cancer Res., 10, 4325-4331.

Kamikawa, A., Ichii, O., Yamaji, D., Imao, T., Suzuki, C., Okamatsu-Ogura, Y., Terao, A., Kon, Y. and Kimura, K. (2009): Diet-induced obesity disrupts ductal development in the mammary glands of nonpregnant mice. Dev. Dyn., 238, 1092-1099.

Kern, P.A., Saghizadeh, M., Ong, J.M., Bosch, R.J., Deem, R. and Simsolo, R.B. (1995): The expression of tumor necrosis factor in human adipose tissue. Regulation by obesity, weight loss, and relationship to lipoprotein lipase. J. Clin. Invest., 95, 2111-2119.

Key, T., Appleby, P., Barnes, I. and Reeves, G. (2002): Endogenous sex hormones and breast cancer in postmenopausal women: reanalysis of nine prospective studies. J. Natl. Cancer Inst., 94, 606616.

Lee, W.M., Lu, S., Medline, A. and Archer, M.C. (2001): Susceptibility of lean and obese Zucker rats to tumorigenesis induced by N-methyl-N-nitrosourea. Cancer Lett., 162, 155-160.

Machinal-Quelin, F., Dieudonne, M.N., Pecquery, R., Leneveu, M.C. and Giudicelli, Y. (2002): Direct in vitro effects of androgens and estrogens on ob gene expression and leptin secretion in human adipose tissue. Endocrine, 18, 179-184.

Maher, M.A., Banz, W.J., Truett, G.E. and Zemel, M.B. (1996): Dietary fat and sex modify heterozygote effects of the rat fatty (fa) allele. J. Nutr., 126, 2487-2493.

Marin Bivens, C.L. and Olster, D.H. (1997): Abnormal estrous cyclicity and behavioral hyporesponsiveness to ovarian hormones in genetically obese Zucker female rats. Endocrinology, 138, 143-148.

Montesano, R., Soulie, P., Eble, J.A. and Carrozzino, F. (2005): Tumour necrosis factor alpha confers an invasive, transformed phenotype on mammary epithelial cells. J. Cell. Sci., 118, 34873500 .

Motta, M., Accornero, P., Taulli, R., Bernabei, P., Desrivieres, S. and Baratta, M. (2007): Leptin enhances STAT-3 phosphorylation in HC11 cell line: effect on cell differentiation and cell viability. Mol. Cell Endocrinol., 263, 149-155.

Oliver, P., Pico, C. and Palou, A. (2001): Ontogenesis of leptin expression in different adipose tissue depots in the rat. Pflugers Arch, 442, 383-390.

Phillips, F.C. and Cleary, M.P. (1994): Metabolic measurements among homozygous (fa/fa) obese, heterozygous $(\mathrm{Fa} / \mathrm{fa})$ lean and homozygous $(\mathrm{Fa} / \mathrm{Fa})$ lean Zucker rat pups at 17 days of age. J. 
Nutr., 124, 1230-1237.

Phillips, M.S., Liu, Q., Hammond, H.A., Dugan, V., Hey, P.J., Caskey, C.J. and Hess, J.F. (1996): Leptin receptor missense mutation in the fatty Zucker rat. Nat. Genet., 13, 18-19.

Rene Gonzalez, R., Watters, A., Xu, Y., Singh, U.P., Mann, D.R., Rueda, B.R. and Penichet, M.L. (2009): Leptin-signaling inhibition results in efficient anti-tumor activity in estrogen receptor positive or negative breast cancer. Breast Cancer Res., 11, R36.

Rouet-Benzineb, P., Aparicio, T., Guilmeau, S., Pouzet, C., Descatoire, V., Buyse, M. and Bado, A. (2004): Leptin counteracts sodium butyrate-induced apoptosis in human colon cancer HT-29 cells via NF-kappaB signaling. J. Biol. Chem., 279, 16495-16502.

Russo, J., Gusterson, B.A., Rogers, A.E., Russo, I.H., Wellings, S.R. and van Zwieten, M.J. (1990): Comparative study of human and rat mammary tumorigenesis. Lab. Invest., 62, 244-278.

Russo, J., Wilgus, G. and Russo, I.H. (1979): Susceptibility of the mammary gland to carcinogenesis: I Differentiation of the mammary gland as determinant of tumor incidence and type of lesion. Am. J. Pathol., 96, 721-736.

Saiduddin, S., Bray, G.A., York, D.A. and Swerdloff, R.S. (1973): Reproductive function in the genetically obese "fatty" rat. Endocrinology, 93, 1251-1256.

Schaffler, A., Scholmerich, J. and Buechler, C. (2007): Mechanisms of disease: adipokines and breast cancer - endocrine and paracrine mechanisms that connect adiposity and breast cancer. Nat. Clin. Pract. Endocrinol. Metab., 3, 345-354.

Schwarzer, K., Doring, H. and Schmidt, I. (1997): Different physiological traits underlying increased body fat of fatty (fa/fa) and heterozygous (+/fa) rats. Am. J. Physiol., 272, E100-6.

Shimizu, H., Shimomura, Y., Nakanishi, Y., Futawatari, T., Ohtani, K., Sato, N. and Mori, M. (1997): Estrogen increases in vivo leptin production in rats and human subjects. J. Endocrinol., 154, 285-292.

Somasundar, P., Frankenberry, K.A., Skinner, H., Vedula, G., McFadden, D.W., Riggs, D., Jackson, B., Vangilder, R., Hileman, S.M. and Vona-Davis, L.C. (2004): Prostate cancer cell proliferation is influenced by leptin. J. Surg. Res., 118, 71-82.
Truett, G.E., Tempelman, R.J. and Walker, J.A. (1995): Codominant effects of the fatty (fa) gene during early development of obesity. Am. J. Physiol., 268, E15-20.

VanPatten, S., Ranginani, N., Shefer, S., Nguyen, L.B., Rossetti, L. and Cohen, D.E. (2001): Impaired biliary lipid secretion in obese Zucker rats: leptin promotes hepatic cholesterol clearance. Am. J. Physiol. Gastrointest Liver Physiol., 281, G393-404.

Wang, X. and Lin, Y. (2008): Tumor necrosis factor and cancer, buddies or foes? Acta. Pharmacol. Sin., 29, 1275-1288.

Waxler, S.H., Tabar, P. and Melcher, L.R. (1953): Obesity and the time of appearance of spontaneous mammary carcinoma in $\mathrm{C} 3 \mathrm{H}$ mice. Cancer Res., 13, 276-278.

Weisberg, S.P., McCann, D., Desai, M., Rosenbaum, M., Leibel, R.L. and Ferrante, A.W. Jr. (2003): Obesity is associated with macrophage accumulation in adipose tissue. J. Clin. Invest., 112, 1796-808.

Wolff, G.L., Kodell, R.L., Cameron, A.M. and Medina, D. (1982): Accelerated appearance of chemically induced mammary carcinomas in obese yellow (Avy/A) (BALB/c X VY) F1 hybrid mice. J. Toxicol. Environ. Health, 10, 131-142.

Wu, M.H., Chou, Y.C., Chou, W.Y., Hsu, G.C., Chu, C.H., Yu, C.P., Yu, J.C. and Sun, C.A. (2009): Circulating levels of leptin, adiposity and breast cancer risk. Br. J. Cancer, 100, 578-582.

You, L., Sar, M., Bartolucci, E.J., McIntyre, B.S. and Sriperumbudur, R. (2002): Modulation of mammary gland development in prepubertal male rats exposed to genistein and methoxychlor. Toxicol. Sci., 66, 216-225.

Zhang, F., Chen, Y., Heiman, M. and Dimarchi, R. (2005): Leptin: structure, function and biology. Vitam. Horm, 71, 345-372.

Zhang, H.H., Kumar, S., Barnett, A.H. and Eggo, M.C. (2000): Tumour necrosis factor-alpha exerts dual effects on human adipose leptin synthesis and release. Mol. Cell. Endocrinol., 159, 79-88.

Zhang, Y., Olbort, M., Schwarzer, K., Nuesslein-Hildesheim, B., Nicolson, M., Murphy, E., Kowalski, T.J., Schmidt, I. and Leibel, R.L. (1997): The leptin receptor mediates apparent autocrine regulation of leptin gene expression. Biochem. Biophys. Res. Commun., 240, 492-495. 